Journal of Social Sciences 5(2): 134-138, 2009

ISSN 1549-3652

(C) 2009 Science Publications

\title{
An Applied Local Wisdom to Manage Water for Developing Riverside Community: A Case Study of the Lam Ta Kong River Basin
}

\author{
${ }^{1}$ Surapong Kongsat, ${ }^{2}$ Anongrit Kangrang and ${ }^{3}$ Kitti Srisa-Ard \\ ${ }^{1}$ The Research Institute of North Eastern Arts and Culture, \\ Mahasarakham University, Maha Sarakham, Thailand \\ ${ }^{2}$ Department of Civil Engineering, Faculty of Engineering, \\ Mahasarakham University, Mahasarakham, Thailand \\ ${ }^{3}$ Faculty of Technology, Mahasarakham University, Mahasarakham, Thailand
}

\begin{abstract}
Problem statement: An integrated water resource management is accepted technique to solve the water resource problems both water shortage and flood plane in order to improve human life. The combination between local wisdom and modern technology by farmer participation is a main part of integrated management. The mentioned techniques had been being applied for human life in the northeast region of Thailand. Approach: This study investigated the local wisdom of water resource management and an application of the local wisdom to manage water resource for developing the economic, society and culture of Lam Ta Kong's community, Nakhorn Ratchasima province, Thailand. Information was investigated from relevant document and field survey including questionnaire and interview. Results: The result founded that there were two types of the local wisdoms including an original local wisdom on water management and a combination of original and modern science local wisdom to manage available water. For original wisdom, there were earth dam, rock dam, rocks dyke, wooden weir, waterwheel and shallow well that were found in source and midst of the river basin. They constructed the dams and weirs barrier flow river along the Lam Ta Kong River in order to storage water for using purposes in dry season and to mitigate flood plane during rainy season as an early age of the local wisdom. The waterwheel was used to bail water from river to their community. For the combination of original and modern science, there were concrete dam, Watergate, irrigating tube, irrigation channel, water pump, water pump dynamo and underground water drilling that were found at the source, midst and tide tail of the river basin. These combined local wisdoms are considered as a current apparatus in water resource management of the area. The stored water was managed with annual rainfall for cultivation, industrial, family activity and residences for the necessaries of life. Conclusion/recommendations: The original local wisdom had the most important role to develop the Lam Ta Kong's community and farmer life from past to present that is disappearing. In the present, the community and farmers still have been being used the combined local wisdom to manage water for developing the economic, society and culture of Lam Ta Kong's Community.
\end{abstract}

Key words: Water resource management, local wisdom, lam Ta Kong river basin, waterwheel

\section{INTRODUCTION}

Nowadays integrated water resource management is an effective solution to solve the water resource problems and to manage available water in order to improve human life. The combination between local wisdom and modern technology by farmer participation is a main part of integrated management. The mentioned techniques have been being applied for human life in the northeast region of Thailand. Also, water resource management is a basically factor of human living since the past to present. It is an important fundamental that is producing the riches on natural resources to the living things in the world. The water resource management in the river basin is to allocate water to land area for using purpose $e^{[1-3]}$. In the present, the water resource management is a resource of difficult for finding inside of demand and more requirements. The water management is the most important matter in many countries and paid more attention to the water resource management which were differed such as the watering management of USA is under the central

Corresponding Author: Surapong Kongsat, The Research Institute of North Eastern Arts and Culture,

Mahasarakham University, Maha Sarakham, 44000 Thailand Tel: +66-43-721686 
government and States government and in China where it is under the responsibility of the National Government, but the management responsibility and the basin maintenance is under the government ${ }^{[4]}$. In the past of the water resource management in Thailand was duty of the government and Thailand's main water management institute is a Department of Irrigation. But it had faced to build the dam because it is affected the environment. Therefore, the official government who ever had a duty to arrange the water turned into the water allocated ${ }^{[5]}$. In addition, there is also the community wisdom such as reservoir or irrigation channel wide spread in the north and northeastern region as well.

Nakorn Ratchasima province, Thailand had grown in the economic and social quite high, especially by Lam Ta Kong River Basin where it is six large communities that they are around the area of Lam Ta Kong River flowing through Moon River Basin and recently faced the problem that was lack of water management ${ }^{[6]}$. In the past the water has been used of agriculture sector and Muang Nakhorn ratchasima municipal for public utility. When the community expanded and social activity increased, the water resource in Lam Ta Kong had been more used on every sector. However, there is the invulnerability with an original community on the water resource management and the water quantity sufficient toward the living earning of Lam Ta Kong community is a "Local wisdom,"[7].

The past of local wisdom for management the water resource of Lam Ta Kong Basin community had depended on the pump up and irrigated from Lam Ta Kong river and Lam Ta Kong reservoir for the necessaries of life, agriculture, family industrial as a local simple thought, for instance, building an earth ditch, wells, a dam for irrigation purpose, irrigation channel, bilge water and shallow wells. The later technology was water pump but presently some types are not in used. Therefore, if the local wisdom on the water management especially the waterwheel is promoted and to be used in the Lam Ta Kong River Basin's water state during in needed, the basin deterioration, pollution and the environment is destroyed, the social contradiction happening. It is because of a high quantity water requirement from Lam Ta Kong will reduce these problems. It is due to a low cost of the local wisdom, no pollution, a good effect that is economized and sufficient to every community.

This study thus the local wisdom of water resource management and an applied the local wisdom to manage water resource for developing the economic, society and culture of Lam Ta Kong's community, Nakhorn Ratchasima province, Thailand (the Northeast Region of Thailand).

\section{MATERIALS AND METHODS}

Study Area: The area of research was Lam Ta Kong River Basin, Nakhon Ratchasima Province, Thailand (Fig. 1). The basin had covered the area of community to 3,874 square kilometers and consisted of six districts and divided into three districts education by the ruling area $^{[7]}$. There were (1) Source of a river was Pak Chong District area (2) Halfway of river source was Si-Khiew, Sung Noen, Kham Thalesor and Muang Nakhon Ratchasima District area (3) The tide tail end was Chaloem Phrakiat District area.

Population and sample group were the populations resided in the Lam Ta Kong River Basin into three areas by Purposive Sampling for 219 persons and divided into 3 groups were (1) Key informants (2) Casual Informants (3) General informants.

This research had a research view scope was the local wisdom on the water resource management and applied the local wisdom on the water resource management for economic, social and culture of Lam Ta Kong's community.

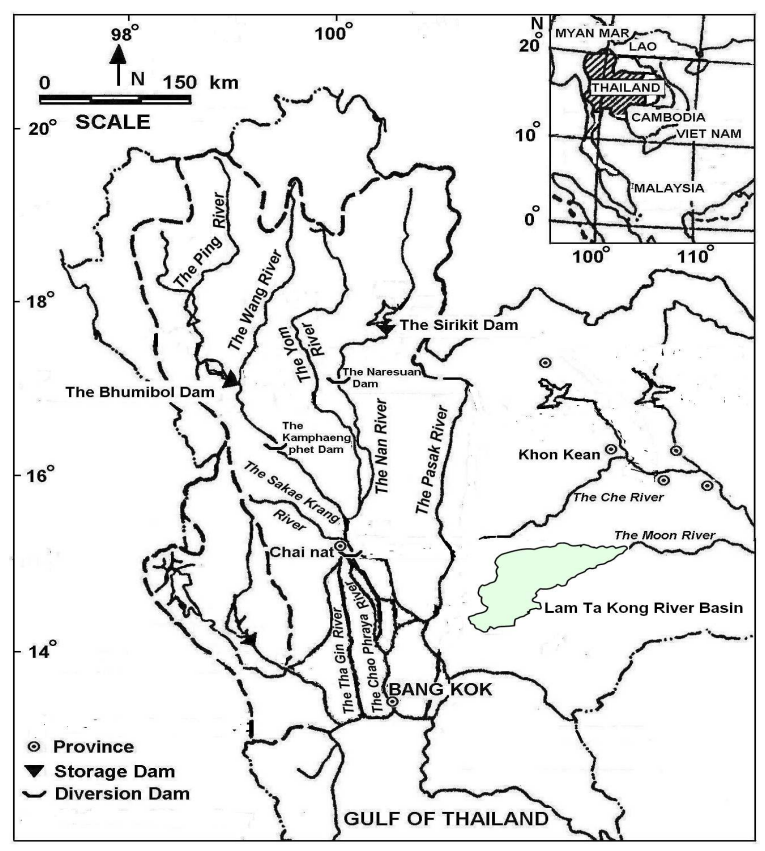

Fig. 1: Location map of Lam Ta Kong River Basin 
Research Method: This study had used the cultural quantitative research in three stages that were the first stage was pre-research that it collected a primary data, the second stage was collected a field data and the third stage was post-research that it was brought the data to analysis by the Cultural Quantitative Research method $^{[8]}$. There were two steps of the data collected that first step was the primary data collection and second step was called Field Data collection by holding the "holistic" principle by the concept of Ngam-pis Sathsanguan and topologically.

The data analyzed was hold the analysis principle that was Analytic Induction and analyzed by topological Analysis.

\section{RESULTS}

Local Wisdom Type: There were two types of the local wisdom to manage the water resource of Lam Ta Kong River Basin's community as the follows. The first type was the original local wisdom including earth dam, rock dam, rocks dyke, wooden weir (Fig. 2), Waterwheel and shallow well that were found in source and midst of the river basin area. These hydraulic constructions were constructed as an early age of the local wisdom or the past. The early age of community built them for managing available water with annual rainfall water for the purpose of agriculture, industrial, family activity and the necessaries of life. Moreover, they constructed the dams and weirs barrier stream flow along the Lam Ta Kong River in order to storage water for using purposes in dry season and to mitigate flood plane during rainy season. The Waterwheel was used to bail water from river to their community for all usages (Fig. 3).

The second type was the original local wisdom combined with a modern technology including concrete dam, Watergate, irrigating tube, irrigation canal, water pump, water pump dynamo and underground water drilling that were found at the source, midst and tide tail of the river basin. These combined local wisdoms were used as the current apparatus in water resource management of the area. The stored water was managed with annual rainfall for cultivation, industrial, family activity and residences for the necessaries of life.

An applied Local Wisdom: An applying the local wisdom to manage water for developing the economic, society and culture of Lam Ta Kong's community that there were above two characteristics as the first type for storage water and divert to used area and the second type for storage water and distribution water including

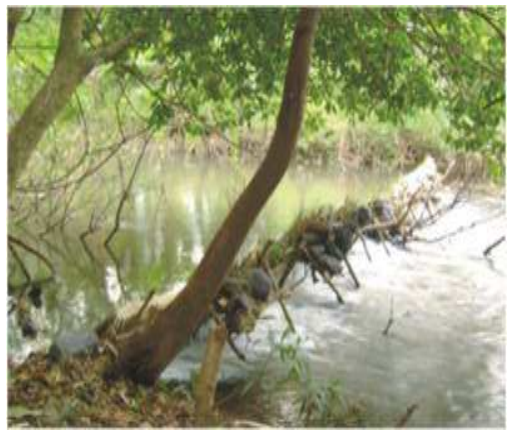

Fig. 2: Wooden weir in Lam Ta Kong River Basin

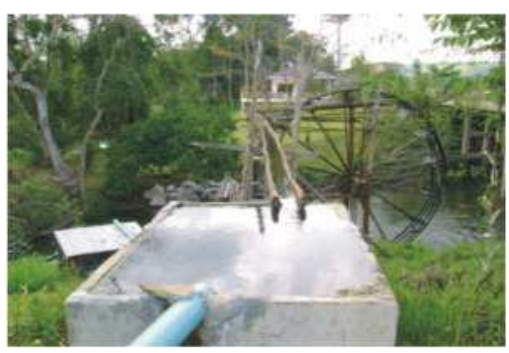

Fig. 3: Waterwheel in Lam Ta Kong River Basin

rainfall, surface and ground water by combined the original local wisdom and modern technology for drinking, domestic usage and agriculture. Lam Ta Kong was importance factor that people had used local wisdoms to take up the water, especially the Waterwheel and other local wisdom to add for making their occupations such as the farmers that manage water until they could done planting in the field 2-3 times year ${ }^{-1}$.

In the present, making the Waterwheel ever uses only wood that it could be use only one year. They had brought a material things and silvers for instead wood in part of wheel, branch of wheel, water machine took water instead the Waterwheel from water pool and water place. Moreover, they had used water dam that people had dig soil pool to send water to area of planting although water spring pool was same material things, there was brought PVC to make water spring. Though it was very expensive, but could use a long time for working. Also, it could remake and keep for use next year.

The cultivation in the Lam Ta Kong River Basin was divided into 3 seasons as summer season (MarchMay), rainy season (May to mid October) and winter season (October-February) respectively. These poor grade paddy farm, Mungo bean, tapioca planting, kitchen garden flowering and fruit plants were in summer season. There were yearly paddy farm, sugar 
cane, corn, kitchen garden vegetables and flowering and fruit plants in rainy season. Whereas, awaited for harvesting, kitchen garden vegetables, flowering and fruit plants were in winter season

\section{DISCUSSION}

There was limit of water in Lam Ta Kong and community had want very much or a lot of water. Management water by local wisdom although it wasn't only local wisdom but community had brought old local wisdom and new technology to change, add and apply for give to use long time. The waterwheel had brought silver or material things to make the wheel, not wood only. Although water machines that community had brought material or silver or steal or dig the water pool, add and mix together for bringing and taking water to planting area, garden and farm very fast. The old local wisdom and new technology that people had managed water, they could develop systems of economic, society, culture and environment of Lam Ta Kong's community since past to present so they had developed perfectly balanced into physics and biology that these activities of society was called "The circuit of life of Lam Ta Kong's community".

Therefore, the Lam Ta Kong's community called this local water energy technology that "waterwheel (Rahad wit nam)" and the name may called differently upon instance such as in the northern region called "Lhuke" whereas some area called "water windmill" or "sail of windmill", ${ }^{88}$. It was believed that the waterwheel was local technology for long been from past to present. There was no evidence that when it was invented. The villagers who used the waterwheel only knew that it was human making and has been used since their ancestors. An old lady aged 77 years who still has strength to do the rice paddy farming said that "I saw the waterwheel since I was a child". According to the studiers of Samutkup ${ }^{[8]}$ regarding Lam Ta Kong waterwheel that the water-wheeler aged 48 year said that "I saw the waterwheel when I was a child. The waterwheel has be done by my ancestors every year when it was deserted they repaired every year". It is considered that the waterwheel is a local wisdom as the water energy along with the agriculturists of Lam Ta Kong basin for long been. Presently, it is found that the waterwheel are widely used along the Lam Ta Kong River Basin such as upper Lam Ta Kong dam in Pakchong District, river, midst in Sikhiew, Sungnoen and Khamthales Districts and the tide end.

The farmers of Lam Ta Kong Basin had simple thought and sort out the rice paddy farm plot that correlated to waterwheel culture in the area that was divided the paddy rice field depending on available water resource and the technology which led the water to its paddy field as follows. Firstly, Bailed rice paddy farm is a river side rice paddy farm. There was location was higher than the banks of the river. The owner built the waterwheel to bail water into their rice paddy farm. This type of the rice paddy field gave a high yield and rich. An old gentleman at Ban Kanong Phra Tai, Pak Chong District said that "the bailed water provided water larger than the pumping water, no fuel consumption, the waterwheel rotating from the day through the night, never mind even it is slower than the water pump". Secondly, Dammed water rice paddy field. There was location was low and no irrigating needed to a very high level but irrigated the water by building a dam for the irrigation purpose or a small irrigation channel to its rice paddy farm. It is also a productive rice paddy farm as well. Thirdly, Rain water rice paddy field. It is a farm that "If it not rain then no rice", relying on a seasonal rain water. Mostly were the pioneered farms afterward. The villagers called type 3 rice paddy farms as "water pumping rice paddy field" and on the modern water pump, pumping the water to its farm during drought or trickling otherwise the villagers were unable to do paddy farming. The water pumped paddy rice field was more costly than the bailed rice paddy farm. The adult aged 35 years who does the rental field at Ban $\mathrm{Na}$ said that "I preferred the bailed rice paddy farm because I do not have to pay for the fuel". He added that "I am an upcountry man, married and settle down at Ban Na, I rented the field for 25 rai $\left(1\right.$ rai $\left.=1600 \mathrm{~m}^{2}\right)$, responsible to do my own bailing, paid for particular year rental at $40 \%$ of the produces, each year I can do annual paddy farming about 130-150 fertilizer gunny bags. For poor grade paddy land with too much water and dry season vegetable plants, the land owner will not charge for the rental. There are still other local wisdoms that were together used with the water irrigating from Lam Ta Kong basin to the agriculture activity purpose that effected to a continued economic and social development and gaining around 45,000-60,000 Baht per year per family or it could be more than that. The Lam Ta Kong community have never rest their works because it is a way of life of every community".

Furthermore, Mrs. Mukda Pomhin was forty-two years old that she said "The Lam Ta Kong's community started from the river source to tide end and most of the occupation are not differed that was a seasonal paddy farm doing then goes to the poor grade paddy land with too much water or planting the Mungo beans, industrial 
vegetables, family activity as it is all year round. This is due the water in Lam Ta Kong was available all year round and maybe more maybe less but the community had depended the local wisdom to manage the water irrigating from the reservoir and from Lam Ta Kong for making the occupations for living all year round".

The used these local wisdoms to manage water from the water retaining, Lam Ta Kong and the seasonal rain water of the community that they could able to earn living within one year and it was brought to develop the economic, social, cultural and environment which had been happening to continued, called "The circuit of life of Lam Ta Kong's community".

\section{CONCLUSION}

The purpose of this study was to study the knowledge of the local wisdom water management of riverside and an applied the local wisdom to manage water for developing the economic, society and culture of Lam Ta Kong community, Nakhorn Ratchasima, province, Thailand. The result founded that there were two categories of the local wisdom to manage the water of Lam Ta Kong's community including an original local wisdom and an original local wisdom combined with a modern technology. The first categories included earth dam, rock dam, rocks dyke, wooden weir, Waterwheel and shallow well that were found in source and midst of the Lam Ta Kong River Basin. These dams and weirs were built barrier flow stream along the Lam Ta Kong River in order to storage water for using purposes in dry season and to mitigate flood plane during rainy season as an early age. The Waterwheel was used to bail water up from river to their community. For the second type, there were concrete dam, Watergate, irrigating tube, irrigation channel, water pump, water pump dynamo and underground water drilling that were found at the source, midst and tide tail of the river basin. These things are functioned in current water resource management of the study area. The stored water was managed with annual rainfall for cultivation, industrial, family activity and residences for the necessaries of life. The two local wisdoms had the most important role to develop the Lam Ta Kong's community from past to present. In the present, the community and farmers still use two local wisdoms to manage the water resource for living until there was stability of the economic, society, culture and environment of theirs community in all time and every year. Further more, these local wisdoms were built occupation for them that called "The cycle of life of Lam Ta Kong's community".

\section{ACKNOWLEDGEMENT}

The researchers would like to express their appreciation to the Mahasarakham University for financial support. The office of water resource region 5 Ministry of natural resource and environment, Project of management the water resource to basin system for supporting data.

\section{REFERENCES}

1. Azeved, L.G., T.K. Gates, D.G. Fontane, J.W. Labadie and R.L. Porto, 2000. Integration of water quantity and quality in Strategic River Basin planning. J. Water Res. Plan. Manage., 126: 85-97. DOI: 10.1061/(ASCE)0733-9496(2000)126:2(85)

2. Shahateet, M.I., 2008. An econometric model for water sector in Jordan. J. Soc. Sci., 4: 264-271. http://www.scipub.org/fulltext/jss/jss44264-271.pdf

3. Seckler, D., U. Amarasinghe, D. Molden, R.D. Silva and R. Barker, 1998. World water demand and supply, 1990-2025: Scenarios and issues, research paper 19.

http://www.lk.iwmi.org/pubs/PUB019/RR019.htm

4. Asadi, A., 2009. Investigation of the agricultural water management mechanisms in Zarindasht Country, Fars province, Iran. J. Agric. Biol. Sci., 4: 110-117.

http://www.scipub.org/fulltext/AJAB/AJAB42110117.pdf

5. Keller, A., J. Keller and D. Seckler, 1996. Integrated water resource systems: Theory and policy implications. Research report 3. http://www.iwmi.cgiar.org/Publications/IWMI_Res earch_Reports/PDF/pub003/REPORT03.PDF

6. Netranimit, 1993. 1500 Years of I-San Chronicle and Heroine of SAMRIT. Mittraphap Company, Nakhorn Ratchasima, Thailand, ISBN: 974-830224-5.

7. The Office of Water Resource Region 5, 2006. Ministry of natural resource and environment, Project of management the water resource to Basin system. Nakhorn Rachasima Joseb, Thailand. http://www.geocities.com/mun_basin5

8. Samuthakup, S., 2004. The Waterwheel of Lam Ta Kong of symbolic science of local water technology. Printed at Thanapres Company, Bangkok, Thailand, ISBN: 978-974-533-615-5. 